\title{
Evaluating the Performance of Horizontal Subsurface Flow Constructed Wetlands Using Natural Zeolite (escott)
}

\author{
Shuib, N., Baskaran, K., V. Jegatheesan
}

\begin{abstract}
The objective of the present study was to assess the simultaneous removal of physiochemical parameters in moderate strength wastewater using a lab scale horizontal subsurface flow constructed wetland (HFCW) with natural zeolite as a substrate. In this study, high-density polyethylene tanks $\left(0.36 \mathrm{~m}^{2}\right)$ were planted with phragmites australis and scirpus maritimus and received $0.012 \mathrm{~m}^{3} / \mathrm{d}$ to $0.08 \mathrm{~m}^{3} / \mathrm{d}$ of synthetic wastewater corresponding to a HLR of 0.035 to 0.243 $\mathrm{m} / \mathrm{d}$ and a COD loading rate of $0.0148 \mathrm{~kg}$ COD $\left(\mathrm{m}^{2} . \mathrm{d}\right)^{-1}$ to 0.026 $\mathrm{kg}$ COD $\left(\mathrm{m}^{2} . \mathrm{d}\right)^{-1}$. The HFCW was subjected to three hydraulic retention times (HRT) for 4,3 and 2 days respectively. Averaged data reported coincided with the plant age (4 to 55 weeks) and covered the entire cold season and early part of the hot season. Based on the 55 weeks of operation, the HFCW unit with zeolite achieved significantly higher removal for COD (85 to $88 \%$ ), TN (54 to $96 \%$ ), $\mathrm{NH}_{4}$-N (50 to $99 \%$ ) and TSS (91 to $96 \%)$ respectively at all HRT. This system was proved to be tolerant to high organic loadings and nutrients, suggesting these substrates as viable options for biological treatment of wastewater.
\end{abstract}

Index Terms - Constructed wetland, horizontal subsurface flow, hydraulic retention time, zeolite

\section{INTRODUCTION}

Constructed wetlands (CWs) has long proven to be an efficient, low-cost and low-maintenance treatment system for various runoff, municipal, industrial and agricultural wastewater in removing organic matter, nutrients and suspended solids. CWs are engineered systems that have been designed and constructed to utilize the natural processes involving wetland vegetation, soils, and their associated microbial assemblages to assist in treating wastewater. They are designed to take advantage of many of the processes that occur in natural wetlands, but do so within a more controlled environment [1].The technology of wastewater treatment by means of CWS with horizontal sub-surface flow (HFCWs) was started in Germany based on research by Kathe Seidel commencing in the 1960s and by Reinhold Kickuth in the 1970s [2]. In these systems the wastewater is fed in at the inlet and flows slowly through the porous medium under the surface of the bed in a more or less horizontal path until it reaches the outlet zone where it is collected before leaving via level control arrangement at the outlet. During this passage the wastewater will come into contact with a network of aerobic, anoxic and anaerobic zones. The aerobic zones occur around roots and rhizomes that leak oxygen into the substrate $[3,4]$. Due to long retention time the HFCWs can provide a reliable secondary level of treatment with regard to organic matter (OM) and

Manuscript received May 25, 2011

S. Nor Lila is with Deakin University, School of Engineering, Pigdons Road, Geelong, Victoria 3217 Australia. Phone: +614 33771526 ; e-mail: (nlshu@deakin.edu.au) total suspended solids (TSS) [9], [10], [23]. It is well documented that the effectiveness of OM and TSS in HFCWs varied from $72.0 \%$ to $95.0 \%$ for suspended solids, $71.2-94.1 \%$ for $\mathrm{BOD}_{5}$ and from $59.7 \%$ to $89.0 \%$ for COD [19].

The use of natural zeolites in environmental applications is spreading due to their properties and significant worldwide occurrence. They are natural materials mined in various deposits and can also be produced synthetically to tailor the properties for specific application. Natural zeolites are crystalline, hydrated alumino-silicates of alkali and earth metals that possess infinite, strong, open, one or threedimensional crystal structure [12], [19]. Natural zeolites have a high ability of riveting microorganisms and removing ammonia and ammonia nitrogen from fluid solutions especially in wastewater treatment [13], [23]. Natural zeolites, in particular clinoptilolite,have been studied extensively for the removal of pollutants from wastewater due to their wide availability and low cost [14], [15], [19]. The main zeolite property exploited in wastewater treatment processes is the ammonium cation $(\mathrm{NH} 4+$ ) exchange ability [19].

The purpose of this study was to evaluate the performance of zeolite as single filter media in treating moderate strength wastewater influent. The main objectives of the present study were: (1) to evaluate the effect of different retention times for the treatment process and (2) to compare the quality improvement using two different substrates. Focus on physiochemical parameters of the wetland outflow after 14 months operation was a priority.

\section{MATERIALS AND METHOD}

Two similar lab-scale horizontal subsurface flow Constructed Wetland (HFWC) units were constructed and operated for approximately 14 months and are still in operation. This is preliminary research of a much larger project containing singles, series HFCW and hybrid CWs. Each HFWC unit was made of high-density polyethylene $0.36 \mathrm{~m}^{2}$ with a depth of $0.44 \mathrm{~m}$. The HFCW unit was divided into three sections by introduction of baffles into the tank to produce a zigzag flow.

The HFCW units were filled with different substrate; being either zeolite $(2-5 \mathrm{~mm})$ or gravel $(10 \mathrm{~mm})$. Cobbles $(10-30 \mathrm{~mm}$ ) were filled at the inlet and outlet zone for both units. The substrate (zeolite and gravel) was filled to a height of $0.4 \mathrm{~m}$. The type of natural zeolite used in this study was escott. Its main composition provided by the supplier, was: $\mathrm{SiO}_{2} 68.26 \%$, $\mathrm{AlO}_{3} 12.99 \%, \mathrm{FeO}_{3} 1.37 \%$, $\mathrm{CaO}$ $2.09 \%, \mathrm{~K}_{2} \mathrm{O} 4.11 \% \mathrm{MnO} 0.06 \%$, MgO $0.83 \%$ and LOI $8.87 \%$. The HFCW unit with gravel (GU) was used as a control media in the system. Two plants were used for both units, namely the common reed ( $\mathrm{R}$, Phragmites australis) and Scirpus maritimus. The plants were collected from 
watercourses in the vicinity of the laboratory in Geelong, Victoria, Australia.

The influent was pumped by peristaltic pumps through the both HFWC units and the water level during the experiment was kept constant at a height of $0.35 \mathrm{~m}$. The hydraulic retention time in the HFCW bed was increased over time. A schematic of the experimental layout is shown in Fig. 1. The system was kept in an indoor area and was supplied by 80 Watt Philips Ecotone high lumen twister hydroponic light at day time with cool daylight $6500 \mathrm{~K}$.

The HFCW units (zeolite (ZU) and gravel (GU)) were fed with synthetic wastewater, which was designed and used to simulate the characteristics of domestic wastewater. The synthetic wastewater contained organic substances and a source of nitrogen, phosphorus and other elements. The organic substances used were peptone $(100 \mathrm{mg} / \mathrm{L})$, with a typical inlet concentration of BOD and COD approximately $300 \mathrm{mg} / \mathrm{L}$ and $450 \mathrm{mg} / \mathrm{L}$, respectively. The source of phosphorus was hydrogen potassium phosphate $\left(\mathrm{K}_{2} \mathrm{HPO}_{4}\right)$ with a typical inlet concentration of $16 \mathrm{mg} / \mathrm{L} \mathrm{PO} 4-\mathrm{P}$. The source of nitrogen was urea with a typical inlet concentration of $80 \mathrm{mg} / \mathrm{L} \mathrm{NH}_{4}-\mathrm{N}$. The flow of synthetic wastewater was varied from 0.012 to $0.08 \mathrm{~m}^{3} / \mathrm{d}$ and the retention times was varied from 4,3 and 2 days. The range of mean surface organic loadings was 0.0148 to $0.026 \mathrm{~kg}$ $\operatorname{COD}\left(\mathrm{m}^{2} / \mathrm{d}\right)^{-1}$ and introduced continuously at the inflow pipes of the wetlands. Synthetic wastewater was used in this study to minimize variations of influent characteristics, safety of laboratory personnel, and solves the problem of transferring significant volumes of wastewater from a distant treatment plant.

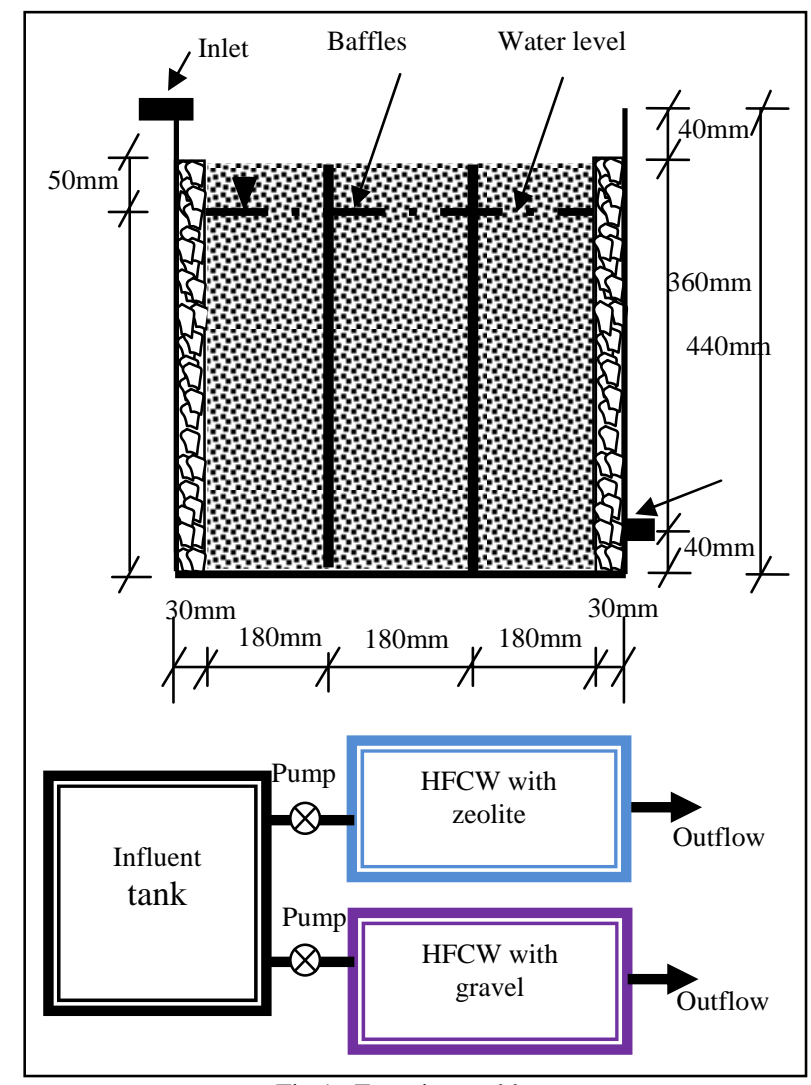

Fig.1. Experimental layout

The experiment works were carried out from January 2010 to the end of January 2011. Averaged data reported coincided with the plant age (4 to 55 weeks) and covered the entire cold season and early part of the hot season. The system was subject to three hydraulic retention time (HRT) of 4, 3 and 2 days. Influent and effluent samples from both units (ZU and GU) were analysed immediately after sampling. All samples were analysed weekly for the following parameters; COD, TN, total-P, $\mathrm{NH}_{4}-\mathrm{N}$, TSS (total suspended solid), conductivity, $\mathrm{pH}$, temperature and dissolve oxygen All parameters were determined based on the methods shown in Table 1.

TABLE 1: The parameters and methods of analyses

\begin{tabular}{|l|l|}
\hline Parameters & \multicolumn{1}{|c|}{ Methods } \\
\hline COD & Merck Cell Test 1.14541 \\
TN & Merck Cell test 1.14763 \\
Total-P & Merck Cell test 1.14729 \\
$\mathrm{NH}_{4}-\mathrm{N}$ & Merck Cell test 1.14763 \\
Conductivity & Conductivity meter WTW LF330 \\
pH & pH meter WTW 320 \\
Temperature & pH meter WTW 320 \\
TSS & Standard Method (1998)[17] \\
Dissolved oxygen & DO meter WTW Oxi320 \\
\hline
\end{tabular}

For testing statistical significance, student's t-test was applied. Independent sample t-test at a significance level of 0.05 was applied to the removal efficiencies of COD, TN, $\mathrm{TP}$ and $\mathrm{NH}_{4}-\mathrm{N}$ for both HFCW units over the 14 months monitoring period. All statistical analyses were performed using SPSS 17.0 for Windows.

\section{RESUlTS AND DisCUSSION}

In order to determine performance of HFCW units, comparison were made between the influent and effluent. The influent and effluent concentrations and percent removal statistics (i.e. mean value, standard deviation, minimum and maximum values) for COD, TN, TP, $\mathrm{NH}_{4}-\mathrm{N}$ and physiochemical parameters of $\mathrm{ZU}$ and GU at different HRT are presented in Table 2 and 3.

Organic matter removal (COD) in the $\mathrm{ZU}$ remained steady during all HRTs which could be seen from the low standard deviation values of removal efficiency (3.61 to 7.71). Mean COD removal was $88 \%$, $85 \%$ and $87 \%$ for HRTs 4, 3 and 2 days, respectively. On contrary to ZU, GU was significantly increased the COD removal when the HRT decreased. The COD removal was $78 \%$ at 4 days HRT and increased to $93 \%$ at 3 and 2 days HRT. The system under the longest HRT operation did not show any increasing of COD removal especially for GU, which might be explained by the presence of non-biodegradable organic compounds in these systems. The COD removal of $\mathrm{CW}$ is mainly relying on microbiological degradation of the matrix attached to and the plant roots [22]. This mechanism responsible for COD reduction were probably bacterial degradation in which oxygen photosynthetically produced by the plants leaves were transferred to the root zones for the bacteria growing in the HFCW beds to biodegrade the organic compounds [16]. The COD removal in this study was within the range of results found by other world-wide researchers. The COD removal varied between $64 \%$ and $82 \%$ respectively [20]. There are three important features possessed by this HFCW system that make the wetland powerful in removing COD under heavy loads. First, owing to the physical separation mechanism, the organic solids could be settled out and retained in the wetland cell for a longer time, thus allowing 
better hydrolysis of organic solids for biodegradation to proceed easily. Secondly, substrate placed inside the wetland cell allowed the accumulation of immense amounts of attached bacteria, which were assisting in catalyzing chemical reactions rapidly. And thirdly, organics biodegradation underwent anaerobic pathway. As such, the limitation of oxygen supply could be avoided, and moreover, maintaining anaerobic conditions inside the wetland cell leads to low sludge production, which can largely prevent the wetland from being clogged by biomass [8]. Figure 2 shows the variation of COD removal for both units at all HRTs.

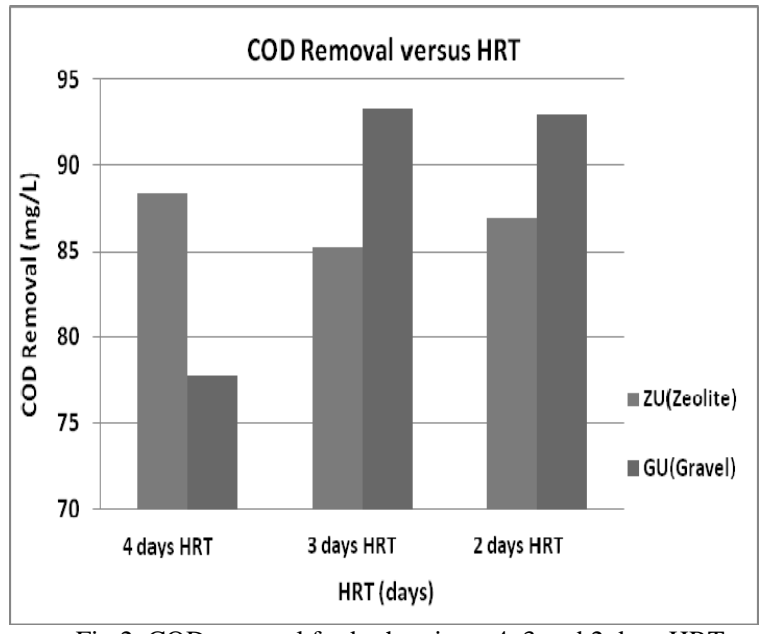

Fig.2. COD removal for both units at 4, 3 and 2 days HRT

The ZU also showed significant removal efficiencies for TN. TN removal was significantly reduced when HRT decreased. TN removal in U1 was significantly higher at a HRT of 4 days compared to at HRTs of 3 and 2 days. The removal was $96 \pm 2.97 \%$ for a HRT of 4 days, $89 \pm 7.93 \%$ and $54 \pm 7.76$ for HRTs of 3 and 2 days, respectively. This is the case in most wetland systems, and it probably occurs because nitrogen removal requires longer HRTs. Beside HRT, TN removal also was influenced by the type of CWs due to their inability to provide both aerobic and anaerobic conditions at the same time. On the contrary to $\mathrm{ZU}$, the GU removed TN with considerably low efficiencies. The mean removal efficiencies of GU at HRTs of 2, 3 and 4 day were $7 \pm$ (3.18) \%, $11 \pm$ (4.71) \% and $43 \pm$ (27.68) \%, respectively. Figure 3 shows the TN variation for ZU and GU at all HRTs.

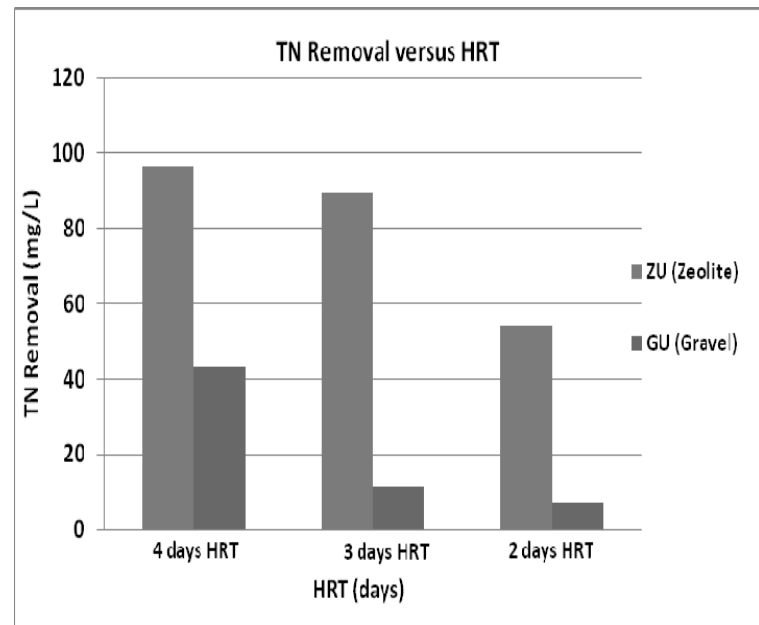

Fig.3. TN removal for both units at 4, 3 and 2 days of HRT

The ZU also showed the greatest removal efficiency for NH4-N. However the NH4-N removal decreased with decreasing HRTs. The mean removal efficiency of NH4-N for ZU at 4 days and 3 days HRT was near to $100 \%$ and reduced to $50 \%$ at 2 days HRT. ZU also showed relatively stable removal of NH4-N during the entire operation period (3 and 4 days HRT), which can be seen from the low standard deviation values of removal efficiency (Table 2). Highest ammonia removal values could be explained by the fact that complete ammonification of organic nitrogen took place and sufficient nitrification in the system. Compared to ZU, NH4-N removal efficiencies in GU was lower for all HRTs. GU showed the increasing of NH4-N in the system. In GU the NH4-N was added to the system when HRT was reduced. The NH4-N in GU increased between $-6 \%,-11 \%$ and $-15 \%$ for HRTs of 4,3 and 2 days, respectively. The removal performance in this unit may be due to litter decomposition, incomplete ammonification of organic nitrogen and insufficient nitrification in the system [17].

TABLE 2: Statistics of overall influent and effluent concentrations as well as removal efficiencies for COD, TN, TP and NH4-N in zeolite (ZU) and gravel (GU) HFCW unit for all HRT

\begin{tabular}{|c|c|c|c|c|c|c|c|c|c|c|c|c|c|c|c|c|}
\hline \multirow[t]{3}{*}{ Parameters } & & \multicolumn{5}{|c|}{2 Days Retention Time } & \multicolumn{5}{|c|}{3 Days Retention Time } & \multicolumn{5}{|c|}{2 Days Retention Time } \\
\hline & & \multirow[t]{2}{*}{$\begin{array}{l}\text { Influent } \\
\text { (mg/L) }\end{array}$} & \multicolumn{2}{|c|}{$\begin{array}{c}\text { Effluent } \\
\text { concentration } \\
(\mathrm{mg} / \mathrm{L})\end{array}$} & \multicolumn{2}{|c|}{ Removal (\%) } & \multirow[t]{2}{*}{$\begin{array}{l}\text { Influent } \\
(\mathrm{mg} / \mathrm{L})\end{array}$} & \multicolumn{2}{|c|}{$\begin{array}{c}\text { Effluent } \\
\text { concentration } \\
(\mathrm{mg} / \mathrm{L})\end{array}$} & \multicolumn{2}{|c|}{ Removal (\%) } & \multirow[t]{2}{*}{$\begin{array}{c}\text { Influent } \\
\text { (mg/L) }\end{array}$} & \multicolumn{2}{|c|}{$\begin{array}{c}\text { Effluent } \\
\text { concentration } \\
(\mathrm{mg} / \mathrm{L})\end{array}$} & \multicolumn{2}{|c|}{ Removal (\%) } \\
\hline & & & $\mathrm{ZU}$ & GU & $\mathrm{ZU}$ & GU & & $\overline{Z U}$ & GU & $\mathrm{ZU}$ & GU & & $\mathrm{ZU}$ & GU & $\mathrm{ZU}$ & GU \\
\hline COD & $\begin{array}{l}\text { Mean } \\
\text { SD } \\
\text { Min } \\
\text { Max }\end{array}$ & $\begin{array}{c}443 \\
20.73 \\
380 \\
473\end{array}$ & $\begin{array}{c}53 \\
36.64 \\
22 \\
137\end{array}$ & $\begin{array}{c}98 \\
47.34 \\
34 \\
178\end{array}$ & $\begin{array}{c}88 \\
7.71 \\
72 \\
95\end{array}$ & $\begin{array}{c}78 \\
10.65 \\
60 \\
92\end{array}$ & $\begin{array}{c}412 \\
19.28 \\
385 \\
434\end{array}$ & $\begin{array}{c}60 \\
15.254 \\
35 \\
84\end{array}$ & $\begin{array}{c}27 \\
21.50 \\
13 \\
91\end{array}$ & $\begin{array}{c}85 \\
4.11 \\
78 \\
92\end{array}$ & $\begin{array}{c}93 \\
5.70 \\
77 \\
97\end{array}$ & $\begin{array}{c}438 \\
28.38 \\
389 \\
482\end{array}$ & $\begin{array}{c}57 \\
15.54 \\
38 \\
95\end{array}$ & $\begin{array}{c}31 \\
10.31 \\
16 \\
47\end{array}$ & $\begin{array}{c}87 \\
3.61 \\
80 \\
91\end{array}$ & $\begin{array}{c}93 \\
2.33 \\
89 \\
97\end{array}$ \\
\hline TN & $\begin{array}{l}\text { Mean } \\
\text { SD } \\
\text { Min } \\
\text { Max }\end{array}$ & $\begin{array}{c}96 \\
15.96 \\
79 \\
123\end{array}$ & $\begin{array}{c}1 \\
1.46 \\
0.80 \\
8\end{array}$ & $\begin{array}{c}58 \\
34.06 \\
5 \\
99\end{array}$ & $\begin{array}{c}96 \\
2.97 \\
90 \\
99.00\end{array}$ & $\begin{array}{c}43 \\
27.680 \\
15 \\
94\end{array}$ & $\begin{array}{c}87 \\
8.02 \\
79 \\
106\end{array}$ & $\begin{array}{c}9 \\
6.3730 \\
2 \\
20\end{array}$ & $\begin{array}{c}78 \\
3.51 \\
71 \\
92\end{array}$ & $\begin{array}{c}89 \\
7.93 \\
76 \\
84\end{array}$ & $\begin{array}{c}11 \\
4.71 \\
4 \\
21\end{array}$ & $\begin{array}{c}87 \\
4.34 \\
81 \\
87\end{array}$ & $\begin{array}{c}40 \\
6.07 \\
29 \\
49\end{array}$ & $\begin{array}{c}82 \\
5.15 \\
75 \\
95\end{array}$ & $\begin{array}{c}54 \\
7.76 \\
43 \\
68\end{array}$ & $\begin{array}{c}7 \\
3.18 \\
2 \\
12 \\
\end{array}$ \\
\hline Total-P & $\begin{array}{l}\text { Mean } \\
\text { SD } \\
\text { Min } \\
\text { Max }\end{array}$ & $\begin{array}{c}10.14 \\
1.11 \\
8 \\
11\end{array}$ & $\begin{array}{c}14 \\
1.45 \\
12 \\
16\end{array}$ & $\begin{array}{c}13 \\
1.38 \\
12 \\
16\end{array}$ & $\begin{array}{c}-40 \\
14.430- \\
56 \\
-16\end{array}$ & $\begin{array}{c}-33 \\
22.24 \\
-69 \\
-9\end{array}$ & $\begin{array}{c}17 \\
1.05 \\
16 \\
19\end{array}$ & $\begin{array}{c}20 \\
1.7413 \\
18 \\
23\end{array}$ & $\begin{array}{c}0.5 \\
0.18 \\
0.3 \\
0.9\end{array}$ & $\begin{array}{c}-20 \\
2.99 \\
17 \\
25\end{array}$ & $\begin{array}{c}-18 \\
10.87 \\
-34 \\
-6\end{array}$ & $\begin{array}{c}16 \\
0.56 \\
15 \\
17\end{array}$ & $\begin{array}{c}19 \\
1.41 \\
17 \\
21\end{array}$ & $\begin{array}{c}21 \\
1.82 \\
19 \\
24\end{array}$ & $\begin{array}{c}-16 \\
6.79 \\
-28 \\
-7\end{array}$ & $\begin{array}{c}-31 \\
10.20 \\
-45 \\
-18\end{array}$ \\
\hline $\mathrm{NH}_{4}-\mathrm{N}$ & $\begin{array}{l}\text { Mean } \\
\text { SD } \\
\text { Min } \\
\text { Max }\end{array}$ & $\begin{array}{c}53 \\
3.24 \\
48 \\
59\end{array}$ & $\begin{array}{c}0.5000 \\
0.0002 \\
0.50 \\
0.80\end{array}$ & $\begin{array}{c}56 \\
3.64 \\
50 \\
62\end{array}$ & $\begin{array}{c}98 \\
0.58 \\
98 \\
99\end{array}$ & $\begin{array}{c}-6 \\
3.75 \\
-15 \\
-0.8\end{array}$ & $\begin{array}{c}57 \\
2.30 \\
55 \\
64\end{array}$ & $\begin{array}{c}0.2 \\
0.24 \\
0.10 \\
0.85\end{array}$ & $\begin{array}{c}57 \\
2.77 \\
52 \\
61\end{array}$ & $\begin{array}{c}99 \\
2.15 \\
60 \\
68\end{array}$ & $\begin{array}{c}-11 \\
3.57 \\
-17 \\
-7\end{array}$ & $\begin{array}{c}55 \\
2.70 \\
51 \\
59\end{array}$ & $\begin{array}{c}27 \\
12.74 \\
6 \\
40\end{array}$ & $\begin{array}{c}62 \\
3.08 \\
59 \\
68\end{array}$ & $\begin{array}{c}50 \\
24.46 \\
23 \\
89\end{array}$ & $\begin{array}{c}-15 \\
4.21 \\
-23 \\
-10\end{array}$ \\
\hline
\end{tabular}


Phosphorus removal in the ZU and GU was significantly lower than $\mathrm{NH}_{4}-\mathrm{N}$, TN and COD. TP removal in $\mathrm{ZU}$ was increased with decreasing HRT. TP removal in this unit was $-40 \%,-20 \%$ and $-16 \%$ at 4,3 and 2 days of HRTs while for GU the removal was $-33 \%,-18 \%$ and $-31 \%$ at 4,3 and 2 days HRTs. TP in ZU and GU showed significant variations during the operation period, as shown by the relatively high values of standard deviation for all HRT. The negative minimum values in the removal performance may be due to litter decomposition and the release of phosphorus back into the system. Phosphorus tends to accumulate in the system because of no significant gaseous loss mechanism. Phosphorus retention by wetlands is regulated by physical (sedimentation and entrainment) and biological mechanisms (uptake and release by vegetation, periphyton, and microorganisms) [6]. A similar behaviour to $\mathrm{P}^{-} \mathrm{PO}_{4}{ }^{3-}$ was observed for total phosphorus (TP), which is the sum of $\mathrm{P}$ $\mathrm{PO}_{4}{ }^{3-}$ and particulate phosphorus (PP) [19]. Reducing conditions (i.e., lack of oxygen, DO concentrations below
$0.1 \mathrm{mg} / \mathrm{L}$ ) can lead to solubilisation of minerals and the release of dissolved phosphorus [7], [17].

Table 3 contains mean removal values of physiochemical parameters, such as electricity conductivity (EC), $\mathrm{pH}$, dissolved oxygen (DO), temperature and total suspended solids (TSS) for both unit (ZU and GU) at all HRT. The removal efficiency in ZU was between 10, 8 and $3 \%$ at 4, 3 and 2 days of HRT. The average EC effluent for U1 was 972, 1116 and $1313 \mu \mathrm{S} / \mathrm{cm}$ for 4,3 and 2 days of HRT. These values were slightly lower when compared to the values for the influent (1084, 1212 and $1355 \mu \mathrm{S} / \mathrm{cm})$ at 4, 3 and 2 days of HRT. For GU, EC removal was varied between 2, 3 and 4 days of HRT. For GU, the removal efficiency of EC was decreased with HRT. The removal was from $-0.60 \%$ to $13 \%$ at 4,3 and 2 days HRT. Compared to all units, the EC removal showed significant variations during the operation period, as shown by the relatively high values of standard deviation at all HRTs. Increased evapotranspiration and/or movement of substrate by plant roots may have accounted for this effect [4].

Table 3: Statistics of overall influent and effluent concentrations and removal efficiencies for physiochemical parameters in zeolite (ZU) and gravel (GU) HFCW unit for all HRT

\begin{tabular}{|c|c|c|c|c|c|c|c|c|c|c|c|c|c|c|c|c|}
\hline \multirow[t]{3}{*}{ Parameters } & & \multicolumn{5}{|c|}{2 Days Retention Time } & \multicolumn{5}{|c|}{3 Days Retention Time } & \multicolumn{5}{|c|}{2 Days Retention Time } \\
\hline & & \multirow[t]{2}{*}{$\begin{array}{c}\text { Influent } \\
\text { (mg/L) }\end{array}$} & \multicolumn{2}{|c|}{$\begin{array}{c}\text { Effluent } \\
\text { concentration } \\
(\mathrm{mg} / \mathrm{L})\end{array}$} & \multicolumn{2}{|c|}{ Removal (\%) } & \multirow[t]{2}{*}{$\begin{array}{l}\text { Influent } \\
\text { (mg/L) }\end{array}$} & \multicolumn{2}{|c|}{$\begin{array}{c}\text { Effluent } \\
\text { concentration } \\
(\mathrm{mg} / \mathrm{L})\end{array}$} & \multicolumn{2}{|c|}{ Removal (\%) } & \multirow[t]{2}{*}{$\begin{array}{l}\text { Influent } \\
\text { (mg/L) }\end{array}$} & \multicolumn{2}{|c|}{$\begin{array}{c}\text { Effluent } \\
\text { concentration } \\
(\mathrm{mg} / \mathrm{L})\end{array}$} & \multicolumn{2}{|c|}{ Removal (\%) } \\
\hline & & & $\mathrm{ZU}$ & GU & $\mathrm{ZU}$ & GU & & $\mathrm{ZU}$ & GU & $\mathrm{ZU}$ & GU & & $\mathrm{ZU}$ & GU & $\mathrm{ZU}$ & GU \\
\hline $\begin{array}{l}\text { Conductivity } \\
(\mu \mathrm{S} / \mathrm{cm})\end{array}$ & $\begin{array}{l}\text { Mean } \\
\text { SD } \\
\text { Min } \\
\text { Max }\end{array}$ & $\begin{array}{l}1084 \\
46.24 \\
1012 \\
1162\end{array}$ & $\begin{array}{c}972 \\
56.56 \\
863 \\
1093\end{array}$ & $\begin{array}{l}1090 \\
46.08 \\
1022 \\
1179\end{array}$ & $\begin{array}{c}10 \\
6.29 \\
3.10 \\
21.10\end{array}$ & $\begin{array}{c}-0.6 \\
6.10 \\
-9 \\
12\end{array}$ & $\begin{array}{l}1212 \\
41.42 \\
1124 \\
1282\end{array}$ & $\begin{array}{c}1116 \\
60.96 \\
5 \\
1016 \\
1204\end{array}$ & $\begin{array}{l}1369 \\
79.87 \\
1236 \\
1476\end{array}$ & $\begin{array}{c}8 \\
3.98 \\
1 \\
14\end{array}$ & $\begin{array}{c}-13 \\
4.248 \\
-20.10 \\
-4.13\end{array}$ & $\begin{array}{c}1355 \\
106.38 \\
1166 \\
1563\end{array}$ & $\begin{array}{l}1313 \\
90.29 \\
1160 \\
1464\end{array}$ & $\begin{array}{c}1525 \\
111.1 \\
5 \\
1365 . \\
5 \\
1715\end{array}$ & $\begin{array}{c}3.036 \\
1.98 \\
0.30 \\
6.30\end{array}$ & $\begin{array}{c}-12.69 \\
3.34 \\
-17.20 \\
-7.30\end{array}$ \\
\hline $\mathrm{pH}$ & $\begin{array}{l}\text { Mean } \\
\text { SD } \\
\text { Min } \\
\text { Max }\end{array}$ & $\begin{array}{l}7.90 \\
0.23 \\
7.70 \\
8.50\end{array}$ & $\begin{array}{l}7.48 \\
0.21 \\
7.00 \\
7.77\end{array}$ & $\begin{array}{l}8.15 \\
0.14 \\
7.90 \\
8.60\end{array}$ & $\begin{array}{c}5.19 \\
4.56 \\
0.30 \\
14.00\end{array}$ & $\begin{array}{c}-3.17 \\
2.21 \\
-6.00 \\
3.20\end{array}$ & $\begin{array}{l}7.69 \\
0.10 \\
7.50 \\
7.80\end{array}$ & $\begin{array}{l}7.47 \\
0.07 \\
7.38 \\
7.57\end{array}$ & $\begin{array}{l}7.99 \\
0.61 \\
7.92 \\
8.10\end{array}$ & $\begin{array}{c}2.93 \\
1.33 \\
0.9 \\
5.80\end{array}$ & $\begin{array}{c}-3.78 \\
1.53 \\
-6.23 \\
-0.96\end{array}$ & $\begin{array}{l}7.76 \\
0.08 \\
7.60 \\
7.90\end{array}$ & $\begin{array}{l}7.53 \\
0.12 \\
7.40 \\
7.80\end{array}$ & $\begin{array}{l}7.87 \\
0.05 \\
7.80 \\
7.90\end{array}$ & $\begin{array}{l}2.94 \\
1.51 \\
0.40 \\
5.10\end{array}$ & $\begin{array}{c}-1.37 \\
0.84 \\
-2.70 \\
0.30\end{array}$ \\
\hline $\begin{array}{l}\text { Dissolved } \\
\text { Oxygen } \\
(\mathrm{mg} / \mathrm{L})\end{array}$ & $\begin{array}{l}\text { Mean } \\
\text { SD } \\
\text { Min } \\
\text { Max }\end{array}$ & $\begin{array}{l}6.10 \\
0.41 \\
5.33 \\
6.86\end{array}$ & $\begin{array}{l}3.82 \\
0.86 \\
2.13 \\
5.15\end{array}$ & $\begin{array}{l}3.57 \\
0.68 \\
1.99 \\
4.98\end{array}$ & $\begin{array}{l}51.13 \\
23.94 \\
23.38 \\
93.24\end{array}$ & $\begin{array}{c}41.12 \\
11.68 \\
8 \\
20.34 \\
69.41 \\
\end{array}$ & $\begin{array}{c}6.84 \\
0.37 \\
6.36 \\
7.5\end{array}$ & $\begin{array}{l}2.04 \\
0.70 \\
1.24 \\
3.93\end{array}$ & $\begin{array}{l}3.06 \\
0.79 \\
1.80 \\
4.87\end{array}$ & $\begin{array}{c}70.29 \\
9.49 \\
46.30 \\
82.10\end{array}$ & $\begin{array}{l}55.26 \\
10.61 \\
33.38 \\
76.05\end{array}$ & $\begin{array}{l}6.02 \\
1.05 \\
4.17 \\
7.12\end{array}$ & $\begin{array}{l}1.46 \\
0.47 \\
1.00 \\
2.50\end{array}$ & $\begin{array}{l}1.83 \\
0.52 \\
1.00 \\
2.40\end{array}$ & $\begin{array}{c}75.73 \\
5.99 \\
63.10 \\
84.10\end{array}$ & $\begin{array}{c}70.12 \\
5.24 \\
64.30 \\
77.70\end{array}$ \\
\hline $\begin{array}{l}\text { Temperature } \\
\left({ }^{\circ} \mathrm{C}\right)\end{array}$ & $\begin{array}{l}\text { Mean } \\
\text { SD } \\
\text { Min } \\
\text { Max }\end{array}$ & $\begin{array}{c}18.98 \\
1.51 \\
16.10 \\
21.50\end{array}$ & $\begin{array}{c}18.87 \\
1.23 \\
16.60 \\
20.90\end{array}$ & $\begin{array}{c}18.83 \\
1.28 \\
16 \\
21\end{array}$ & $\begin{array}{c}0.42 \\
3.62 \\
-6.60 \\
9.10\end{array}$ & $\begin{array}{c}0.75 \\
3.66 \\
-8.20 \\
7.90\end{array}$ & $\begin{array}{c}14.07 \\
1.64 \\
10.9 \\
16.9\end{array}$ & $\begin{array}{c}13.69 \\
1.58 \\
11.40 \\
15.90\end{array}$ & $\begin{array}{c}13.74 \\
1.74 \\
10.80 \\
16.35\end{array}$ & $\begin{array}{c}14.07 \\
1.64 \\
10.90 \\
16.90\end{array}$ & $\begin{array}{c}2.31 \\
5.81 \\
-4.61 \\
14.75\end{array}$ & $\begin{array}{l}18.41 \\
1.46 \\
15.3 \\
20.9\end{array}$ & $\begin{array}{c}18 \\
1.37 \\
15.30 \\
20.80\end{array}$ & $\begin{array}{l}18.15 \\
1.26 \\
15.6 \\
19.9\end{array}$ & $\begin{array}{c}2.11 \\
2.27 \\
-0.90 \\
6.30\end{array}$ & $\begin{array}{c}1.293 \\
2.01 \\
-2.30 \\
5.00\end{array}$ \\
\hline $\begin{array}{l}\text { Total } \\
\text { suspended } \\
\text { Solids (mg/L) }\end{array}$ & $\begin{array}{l}\text { Mean } \\
\text { SD } \\
\text { Min } \\
\text { Max }\end{array}$ & $\begin{array}{c}0.2640 \\
0.22 \\
0.04 \\
0.71\end{array}$ & $\begin{array}{c}0.0096 \\
0.01 \\
0.004 \\
0.03\end{array}$ & $\begin{array}{c}0.0091 \\
0.01 \\
0.002 \\
0.04\end{array}$ & $\begin{array}{c}95.94 \\
3.22 \\
88.72 \\
99.37\end{array}$ & $\begin{array}{c}94.53 \\
4.40 \\
82.22 \\
98.69\end{array}$ & $\begin{array}{c}0.429 \\
0.02 \\
0.02 \\
0.09\end{array}$ & $\begin{array}{c}0.003 \\
0.003 \\
0.002 \\
0.01\end{array}$ & $\begin{array}{c}0.0040 \\
0.004 \\
0.002 \\
0.1\end{array}$ & $\begin{array}{c}91.274 \\
6.96 \\
80.00 \\
98.80\end{array}$ & $\begin{array}{c}90.207 \\
7.49 \\
73.80 \\
98.80\end{array}$ & $\begin{array}{c}0.053 \\
0.01 \\
0.03 \\
0.07\end{array}$ & $\begin{array}{c}0.002 \\
0.001 \\
0.001 \\
0.01\end{array}$ & $\begin{array}{c}0.003 \\
0.002 \\
0.001 \\
0.01\end{array}$ & $\begin{array}{c}96.14 \\
2.79 \\
90.2 \\
98.6\end{array}$ & $\begin{array}{c}94.61 \\
3.03 \\
89.5 \\
98.20\end{array}$ \\
\hline
\end{tabular}

Total suspended solids (TSS) include all particles suspended in water that will not pass through a filter. In constructed wetlands, TSS are removed mainly by physical processes such as sedimentation and filtration [5] followed by aerobic or anaerobic microbial degradation inside the substrate [11]. These processes are achieved when the wastewater passes through the system at a low velocity because of the presence of vegetation and the substrate [7]. The TSS concentrations in this study remained relatively stable over the course of the sampling season. The TSS removal ranged between $90 \%$ to $96 \%$ for both units. The TSS removal efficiencies observed in both units were within the range of results found by other researchers using similar systems. The TSS removal from several studies ranged between $72 \%$ to $95 \%$ [11], [19], [21].
Average temperature in influent and effluent of both units were comparable during all HRT. The temperature for $\mathrm{ZU}$ and GU at all HRT ranged from $14^{\circ} \mathrm{C}$ to $20^{\circ} \mathrm{C}$. Many biogeochemical reactions proceed at a faster rate as the temperature of the medium is increased. Optimal temperature for maximum microbial activity may vary depending on the interactive factors such as hydraulic loading, effluent quality, vegetation, and soil and substrate within the wetland [6]. In this study temperature was determined not to be statistically significant for the removal of the physiochemical parameters.

Results showed the concentration of DO reduced with the decrease of HRT in all units. DO concentration varied significantly for the $\mathrm{ZU}$ unit. The average DO concentration in $\mathrm{ZU}$ was 3.82, 2.04 and $1.46 \mathrm{mg} / \mathrm{L}$ at 4,3 and 2 days of 
HRT respectively. The average DO levels in the GU at 4, 3 and 2 days of HRT remained almost constant. The DO value for $\mathrm{GU}$ was ranged from 1.83 to $3.57 \mathrm{mg} / \mathrm{L}$, respectively and results suggested that the extent of biodegradation and oxygen consumption was highest in $\mathrm{ZU}$ unit

The $\mathrm{pH}$ of $\mathrm{ZU}$ remained relatively neutral, fluctuating between 7.47 and 7.53 for all HRTs. For 3 and 2 days of HRT, the $\mathrm{pH}$ value in $\mathrm{ZU}$ was almost constant between 7.47 and 7.45. Contrast to U1, $\mathrm{pH}$ in GU unit was more alkaline with an average of $8.15,8.0$ and 7.87 at the HRTs of 4,3 and 2 days, respectively. On the whole, $\mathrm{pH}$ value tends to be at neutral or slightly basic, possibly due to interactions between the substrate and biofilms in the treatment systems.

Results of independent t-tests $(\mathrm{p}<0.005)$ indicated a significant reduction of COD, TN, TP and $\mathrm{NH}_{4}-\mathrm{N}$ at 4,3 and 2 days HRT for both HFCW units. The removal efficiencies of both HFCW units (zeolite and gravel) showed differences for all evaluated parameters during treatment at 4, 3 and 2 days HRT.

\section{CONCLUSIONS}

Two lab-scale horizontal subsurface flow constructed wetlands using natural zeolite-filters were operated for approximately 55 weeks and showed a satisfying removal efficiency of organic matter, TN and ammonia. Removal efficiencies proved to be considerably high for these parameters, while removal rates of phosphorus appeared to be lower than those of nitrogen. The zeolite and gravel HFCW unit showed significant differences in the ability to reduce COD, TN, TP and NH4-N at the 43 and 2 days HRT. Zeolite-filters proved to substantially improve the effluent quality of the constructed wetlands. These results suggest that it is possible to use zeolite as a filter media for better quality effluent of wastewater. A simple mineralogical survey of filter materials for the zeolites may render many installations of constructed wetlands successful.

\section{REFERENCES}

[1] H. Brix. (1987).Treatment of wastewater in the rhizosphere of wetland plants-the root zone method. Water Science and Technology. [Online]. (19). pp. 107-118. Available: http://mit.biology.au.dk/ biohbn/hansbrix/pdf_files/Wat_Sci_Tech_1 9\%20(1987)\%20107-118.pdf

[2] P. E. Cooper, G. D. Job and M. B. Green, Reed Beds and Constructed Wetlands for Wastewater Treatment, United Kingdom: WRc Publications, Medmenham, Marlow, Bucks, 1996

[3] D. A Hammer and R. K. Bastian. Wetlands ecosystems: natural water purifiers?, in Constructed wetlands for wastewater treatment, D.A. Hammer, Editor. Lewis Publishers: Chelsea, Michigan, 1989, pp. 5-9.

[4] K. R. Hench, et al. (February 2003). Fate of physical, chemical, and microbial contaminants in domestic wastewater following treatment by small constructed wetlands. Water Research. [Online]. 37(4), pp. 921-927. 2/2/6b9be6c5f474b2938b378977ca220440

[5] R. H. Kadlec and R.L. Knight. Treatment Wetlands. USA: Boca Raton : Lewis Publishers, 1996, pp. 893.

[6] R. H. Kadlec and K.R. Reddy. (September 2001). Temperature Effects in Treatment Wetlands. Water Environment Research. [Online]. 73(5), pp. 543-557. Available: http://www.jstor.org/stable/25045537

[7] R. H. Kadlec and S.D. Wallace. Treatment Wetlands. Boca Raton, FL CRC Press/Lewis Publishers, 2008

[8] C. -Y. Lee Lee, C.-C. Lee, F-Y Tseng and S. Kung. (April 2004). Performance of subsurface flow constructed wetland taking pretreated swine effluent under heavy loads. Bioresource Technology, [Online]. 92(2),
http://www.sciencedirect.com/science/article/B6V24-49Y9BRD5/2/8e966028b2ace5914a391d986bba3e0e:

[9] U. Mander and W.J. Mitsch. (February 2009). Pollution control by wetlands. Ecological Engineering. [Online]. 35(2), pp. 153-158. Available: ticle/B6VFB-4VJ5V4B1/2/cad76d188http://www.sciencedirect.com/science/aredcc6ee1763a 322eb1fe3e0

[10] T. Manios, E.I. Stentiford, and P. Millner. (2003) The removal of chemical oxygen demand from primary-treated domestic wastewater in surface-flow reed beds using different substrates. Water Environment Research. [Online]. 75(4), pp. 6.

[11] G. Merlin, J.-L. Pajean, and T. Lissolo. (2002) Performances of constructed wetlands for municipal wastewater treatment in rural mountainous area. Hydrobiologia. 2002. 469(1-3), pp. 12.

[12] Z. Milán, et. al. (October 2001. Influence of different natural zeolite concentrations on the anaerobic digestion of piggery waste. Bioresource Technology. [Online]. 80(1), pp. 37-43. http://www.sciencedirect.com/science/article/B6V24-43N2W205/2/92daa49dd5c94e375d4f6ff61a783ee6

[13] M. Noori,, M. Zendehdel, and A. Ahmadi. Using Natural Zeolite for the Improvement of Soil Salinity and Crop Yield. Toxicol. Environ. Chem, 2006. (88), pp. 77-84.

[14] M. Pansini. Natural zeolites as cation exchangers for environmental protection. Miner Depos, 1996, (31), pp. 12.

[15] S. C. Reed, R.W. Crites, and E.J. Middlebrooks. Natural Systems for Waste Management and Treatment. 1995, USA: McGraw-Hill, Inc, .

[16] V. Sawaittayothin and C. Polprasert.(February 2007). Nitrogen mass balance and microbial analysis of constructed wetlands treating municipal landfill leachate. Bioresource Technology. [Online]. 98(3), pp. 565-570. Available: http://www.sciencedirect.com/science/article/B6V24-4JHMHR71/2/a928c35dae00ad2f12b5c4db40967ce4

[17] Standard Methods for Examination of Water and Wastewater. $2^{\text {nd }}$ edition, 1998.

[18] A. I. Stefanakis, et al.(August-September 2009). Effluent quality improvement of two pilot-scale, horizontal subsurface flow constructed wetlands using natural zeolite (clinoptilolite). Microporous and Mesoporous Materials. [Online]. 124(1-3), p.p 131-143. Available: http://www.sciencedirect.com/science/article/B6TH4-4W7YY013/2/aa9e00e3bd82e7a0c636799313091468

[19] A. Tuszynska and H. Obarska-Pempkowiak.(September 2008) Dependence between quality and removal effectiveness of organic matter in hybrid constructed wetlands. Bioresource Technology. [Online]. 99(14), pp. 6010-6016. Available:http://www.sciencedirect.com/science/article/B6V244RPD7BB-2/2/786715e2d8804b0e6d8e4cd4ee043bbd

[20] J. Vymazal. (July 2007). Removal of nutrients in various types of constructed wetlands. Science of The Total Environment. [Online]. 380(1-3): pp. 48-65. Available: http://www.sciencedirect.com/science/article/B6V78-4M7K9MY4/2/fb43994ce7bf34149cb0ca3e9dcdcbd2

[21] J. Vymazal. (June 2009). The use constructed wetlands with horizontal sub-surface flow for various types of wastewater. Ecological Engineering. [Online]. 35(1), pp. 1-17. Available: http://www.sciencedirect.com/science/article/B6V78-4THS3F56/2/e90b42d0ce5795afc9daf163b18c1973

[22] Q. Yang, et al. (April 2007). Contaminant Removal of Domestic Wastewater by Constructed Wetlands: Effects of Plant Species. Journal of Integrative Plant Biology. [Online]. 49(4), pp. 437-446. http://dx.doi.org/10.1111/j.1744-7909.2007.00389.x

[23] F. Zurita, J. De Anda, and M.A. Belmont. (May 2009). Treatment of domestic wastewater and production of commercial flowers in vertical and horizontal subsurface-flow constructed wetlands. Ecological Engineering. [Online]. 35(5): pp. 861-869. http://www.sciencedirect.com/science/article/B6VFB-4VJBCJC1/2/8191eacc66bf06a9c8d5db22a5823c8d

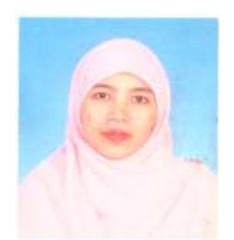

Nor Lila was born in Bukit Besar, Kedah, Malaysia on 20 of June 1968. She received her BSc degree from the Universiti Teknologi Malaysia (2000) and MSc degree from Universiti Sains Malaysia (2004) She was employed as a lecturer in the Civil Engineering at Universiti Tenologi Mara (UiTM), Malaysia since 2004. At present she is a PhD. student at the School of Engineering and Information Technology at Deakin University, Australia. Her current interests include the constructed wetland treatment, water and wastewater treatment. 